
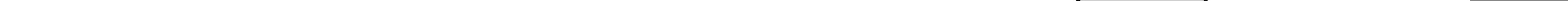


\title{
LA TRAMOYA DEL LENGUAJE, O LA PALABRA INTERIOR: LA FUERZA HERMENÉUTICA DE LA METÁFORA
}

\section{THE MACHINATIONS OF LANGUAGE, OR THE INNER WORD: THE HERMENUTIC POWER OF METAPHOR}

\author{
José L. SERRANo Ribeiro* \\ UNED
}

\begin{abstract}
RESUMEN: El propósito general de este trabajo, aparte de prestar atención a la tramoya del lenguaje para habilitar la relevancia hermenéutica del lenguaje interior, — que es como la parte sumergida de un iceberg-, es mostrar que las metáforas, en este sentido, funcionan como un medio eminente de interpretación y, por lo tanto, como una manera más de poner en evidencia el aspecto universal que presenta la hermenéutica, que no es otro que el deseo que insiste en el verbum interius: querer decir y querer comprender. Examinando la distinción entre la palabra interior y la exterior, pretendemos extraer algunas consideraciones interesantes que nos puedan servir para entender mejor el valor y el sentido de las experiencias que suscitan las metáforas, como fenómenos originarios de apropiación.
\end{abstract}

PALABRAS ClAVE: Palabra interior (verbum interius), voz de la conciencia, lenguaje, hermenéutica, metáfora, deseo.

ABSTRACT: The general proposal of this paper, apart from giving attention to the machinations of language in order to

* E-mail: joxelserrano@hotmail.com 
enable the hermeneutic relevance of the interior language, - which is like the submerged part of an iceberg-, is to show that the metaphors, in this sense, work like an eminent means of interpretation and, therefore, as another way to show the universal aspect that hermeneutics present, which is none other than the desire that insists on the verbum interius: to want to say and to want to understand. Examining the distinction between the interior word and the exterior word, we try to extract some interesting considerations that can help us understand better the value and the meaning of the experiences that the metaphors arouse, inasmuch as original phenomena of appropriation.

KEYWORDS: Inner word (verbum interius), voice of consciousness, language, hermeneutics, metaphor, desire.

\section{Introducción}

En la mayoría de los trabajos que tratan sobre el lenguaje, éste suele quedar reducido a su estado sólido, es decir, a su consistencia plasmada en palabras proferidas de acuerdo con unas reglas de uso (pragmática), de significado (semántica) y de composición (sintaxis y gramática). Nosotros defendemos que también es lenguaje de pleno derecho la trama fluida que se expande y se contrae en nuestro interior sin ser dicha, esa urdimbre apalabrada que tejemos en silencio como un diálogo de preguntas y respuestas que siempre nos acompaña con la apariencia de voces secretas, y que está acompasada con el latido insistente de pensamientos y sentimientos. Ante ese diálogo privado que nos autentifica y sostiene no se nos ocurre decir que "oímos voces», como sucede en algunas patologías psicológicas severas, sino que reconocemos el fenómeno como algo totalmente natural, identificándonos con él hasta el punto de obtener desde este trasfondo fontanal las proferencias que empleamos, aunque tengamos la sensación de que nos sobrevienen de repente y casi sin querer, porque eso es en realidad lo que somos, "una voz interior que habla y en cuyo diálogo nos encontramos a nosotros mismos» (Lledó, 1998a, pp. 160-161).

Si las proferencias externas son secuenciales y monofónicas, las palabras internas son concurrentes y polifónicas. Se trata de algo parecido a lo que sucede en música: como sólo es posible entonar una voz al cantar, la armonización concu- 
rrente corre el riesgo de perderse. ¿Qué hacer, entonces, para que un supuesto espectador comprendiese el «significado armónico» de una canción sin la ayuda de otro instrumento que la voz? ¿Cómo formaríamos en el exterior público el contexto armónico que resonó en nuestro interior, y que define el «valor semántico» de la melodía? No tendríamos más remedio que enseñar a nuestro espectador la primera voz para cantar nosotros la segunda sobre la suya; y esto ejemplifica lo que ocurre en el lenguaje: la forma de exteriorizar una pequeña parte del verbum interius que nos constituye, es deshilando poco a poco en las conversaciones esas hebras que se cruzan, anudan y entrelazan con las del otro. Solamente así es posible pasar de lo monofónico a lo polifónico, de la semántica congelada en los nichos del diccionario al sentido proyectivo y direccional de la comprensión, del significado normalizado y objetivo de las proferencias a la hermenéutica que compromete la palabra interior de quienes dialogan: «esta atención al sentido interior puede llamarse "hermenéutica" (Grondin, 2005, p. 60). Todo proceso dialógico o hermenéutico, incluido el metafórico, se resuelve en el mismo plano lingüístico que ocupa el verbum interius, verdadero lecho de comprensión en donde se arman y despejan las metáforas, un espacio habilitado por la fuerza que el deseo impone, pues "la metáfora y el diálogo se identifican en sus fines» (López, 2000, p. 248), ambos buscan el entendimiento.

\section{La función hermenéutica de la metáfora}

Será interesante a continuación recoger algunas teorías sobre la metáfora, con la única intención de mostrar que en cada una subyace, latente o expresamente, una función hermenéutica, porque la metáfora tiene el poder de interpretar, porque "la capacidad metafórica del lenguaje está en la base del acto hermenéutico» (López, 2000, p. 242). Pero antes daremos cuenta de la idea básica de interpretación que queremos manejar. En Gadamer se puede hallar la noción más concisa y acertada: «Tomar algo por algo es interpretar» (Gadamer, 2000, p. 32). El núcleo de la estructura de esta fórmula es el als («por») del etwas als etwas («algo por algo»), que también se podría traducir al castellano por "como» o "en cuanto" para obtener fórmulas similares: «tomar algo "como" algo» o «tomar algo "en cuanto” algo» (es interpretar). Esta ecuación hermenéutica presentada por Gadamer procede de Heidegger: "lo comprendido expresamente, tiene la estructura del algo como algo» (Heidegger, 1993, $\$ 32$, p. 167), y ha sufrido algunos cambios en su forma, aunque el espíritu haya quedado intacto: interpretar es hacer fami- 
liar lo extraño, esto es, «la interpretación (...) convierte en algo propio lo que, en un principio, era extraño» (Ricoeur, 1999, p. 75). Se trata de un proceso de asimilación que podría ser ilustrado con el de la elaboración de los vinos de solera: el vino de la nueva cosecha (el primer algo, lo «extraño») es mezclado con porcentajes regresivos de las cosechas anteriores (el segundo algo, lo «familiar»). Un jerez añejo y fino mejora otro más joven: el vino nuevo, aún extraño y ajeno, es «interpretado» y tratado conforme a los vinos más antiguos y conocidos, y como resultado se obtiene un vino que será a su vez empleado, en parte, para repetir la misma operación en el futuro.

Si tenemos en cuenta estas dos ideas elementales sobre lo que es interpretar, no deberá extrañar entonces que sea posible nivelar funcionalmente cualquier proceso de metaforización con otro hermenéutico, pues las metáforas hacen exactamente lo mismo que la interpretación: tomar algo como algo y convertir en familiar lo extraño. Por ejemplo, la metáfora que toma «unos ojos» por «constantes brillos de un imán», interpreta también en la medida en que revela una perspectiva, anteriormente oculta y latente, al convertirla en una vía de acceso reconocible y familiar gracias a la propia operación hermenéutica que logra activar, es decir, "una metáfora ofrece una "perspectiva": La metáfora es un artificio para ver algo en términos de otra cosa (...). Y considerar a $A$ desde el punto de vista de $B$ es (...) utilizar a B como una "perspectiva" para A» (Turbayne, 1974, p. 35).

La mayoría de las teorías sobre la metáfora han fijado la atención en la semántica, es decir, en lo que las palabras significan según su uso cotidiano, para descubrir sustituciones, similitudes, concordancias, tensiones y comparaciones. Otras la han entendido como un asunto puramente pragmático, como Grice, Searle y Davidson, quienes sostienen la distinción entre el significado propio de las palabras y el que pretende el hablante. El problema fundamental que desde el punto de vista pragmático plantean las metáforas es un caso particular de explicar cómo el significado del hablante y el significado de la oración o de la palabra siguen caminos separados. Esto es: se trata de un caso especial de cómo es posible decir una cosa y querer decir algo distinto" (Searle, 1999, pp. 588-589). Y cuando se ha querido comprenderlas en función del contexto, no se ha tenido en cuenta que éste no viene dado de una vez por todas, sino que se va formando progresivamente a base del entrecruzamiento de proferencias. Aunque lo más decepcionante para la perspectiva hermenéutica, ha venido de la mano de las teorías que han descalificado el uso de metáforas por considerar que pervierten el «verdadero» signi- 
ficado de las palabras, como si sus acepciones hubieran sido siempre las mismas, cuando lo cierto es que no han dejado de variar. Quien más se cree libre de las metáforas más sumido está en ellas (Unamuno); porque renunciar a las metáforas es como renunciar a contemplar la realidad desde algún punto de vista (Ortega); porque es imposible expresarse sin metáforas; porque la distinción entre lo literal y lo metafórico sólo es una «antigualla semántica» (Ricoeur); porque toda expresión admite más de una lectura (E. Romero); porque asociar lo literal a lo convencional y lo metafórico a lo no convencional sólo es un capricho injustificado; porque las metáforas no requieren de un tiempo extra para ser procesadas mentalmente (C. Gallego); y además, el lenguaje uniformado, monovalente, unívoco y supuestamente literal, es el que se utiliza para el control social, para generar indiferencia ante lo poético, lo emotivo y los deseos realmente propios (Gardner y Winner).

Somos conscientes de que la postura que defiende la metaforicidad fundamental del lenguaje, podría suscitar algunas críticas como, por ejemplo, pensar que si extendemos la metáfora a todo el lenguaje, dejaría de significar algo concreto dentro del universo lingüístico, pues al borrar la distinción entre lo metafórico y lo literal no tendría sentido especificar que una palabra es metafórica. Además, el hecho de que la metáfora esté más presente de lo que solemos percibir, no implica que todo el lenguaje sea metafórico ya que habría un salto abusivo que privaría a la metáfora de su propio significado. Pero lo que afirmamos es que cualquier portador de significado puede ser interpretado en clave metafórica, porque todo significante se halla inserto en un contexto determinado. Además, un discurso estrictamente literal no estaría soportado por el lenguaje natural y vivo del diálogo, sino que sólo se trataría de un metalenguaje. No hay palabras, frases y discursos marcados previamente como literales o metafóricos, sino que pueden llegar a serlo en virtud de la interpretación que les prestemos según las circunstancias en las que se produzcan. La metaforicidad fundamental del lenguaje significa que no hay parte alguna de éste exenta de un posible funcionamiento metafórico: cualquier fragmento de texto puede convertirse en metáfora. Por otra parte, la relevancia que concedemos en este trabajo a la metáfora está en función de sus poderes hermenéuticos, y por ello defendemos la metaforicidad fundamental del lenguaje, ya que uno de nuestros objetivos es asimilar el proceso metafórico con el hermenéutico, sobre todo para situar tal actividad en el campo lingüístico del verbum interius, magma en ebullición saturado de energía deseante. 
Para Aristóteles la metáfora consiste en una permuta de nombres. Es un modo no usual pero comprensible de nombrar captando las similitudes de los referentes: "metáfora es la aplicación a una cosa de un nombre que le es ajeno; tal traslación puede ser de género a especie, de especie a género, de una especie a otra especie o por analogía (Aristóteles, 2002, Poética 1457b, pp. 114-115). El carácter hermenéutico de esta teoría es obvio, pues si metaforizar es decir el nombre ajeno por el familiar, resultará que no es más que interpretar, pues afianza una acepción nueva sobre la comúnmente usada, (sobre todo en el registro poético). Cicerón (De oratore) y Quintiliano (Institutio Oratoria) transmitieron la concepción aristotélica: la metáfora es un símil abreviado $(x$ es $y$ ) o una comparación contraída ( $x$ es como $y$ ) (cfr. Bustos, 2000, p. 14). El rendimiento hermenéutico de esta versión es evidente, pues reasigna los términos que expresan los referentes provocando su mejor comprensión.

Antes de que en el siglo XVIII la metáfora se concibiese, sobre todo en la visión romántica e idealista, como el fundamento del lenguaje y se afirmara la metaforicidad fundamental de éste con Herder y Humboldt (hasta Nietzsche, Gadamer, Derrida y Ricoeur), el empirismo la consideró como un extravío lingüístico que era preciso suprimir, y más en los discursos científicos que describen y explican la realidad, para reservarla exclusivamente a los retóricos que intentan conmover conciencias (cfr. Locke, 1994, III, XX, 34, p. 503). Pero Locke fue incapaz de seguir su propia recomendación, pues con cierta frecuencia recurrió a la metáfora para exponer su filosofía. Recordemos el valor hermenéutico de las metáforas del papel en blanco o de la tabula rasa para indicar que la mente carece de ideas hasta que las adquiere por la experiencia. Pascal rehabilitó la metáfora como un recurso hermenéutico porque, según él, lo expresado metafóricamente no es parafraseable de modo literal. En efecto, el significado metafórico de una expresión es independiente del significado literal que generan sus elementos tomados en sus acepciones habituales. Con la metáfora se pretende aludir a la parte más sutil del espíritu hablándole en su propio idioma (cfr. Villar, 1988, p. 105), es más, se establece un hilo directo con el verbum interius de cada cual. Vico consideró la metáfora como la esencia del lenguaje, como uno de los tropos más eminentes para comprender la realidad: «el más luminoso (...), más necesario y más frecuente es la metáfora» (Vico, 1985, II, II, V, [409], p. 176). Hegel, por su parte, pensó que el funcionamiento de la metáfora se debía a la transferencia del significado de una palabra que al principio pertenecía al orden natural y sensible, al dominio de lo espiritual, esto es, un traslado desde el con- 
texto material hasta el ideal, y viceversa (cfr. Hegel, 1983, p. 177). Por esto, la metáfora constituye una clave hermenéutica de primer orden, pues aproxima el mundo de lo desconocido al conocido al comprender lo arcano en términos de lo común.

Pero es con Nietzsche cuando la metáfora se erige en el factor genético del lenguaje: la actividad metafórica se puede reducir a un conjunto de procesos hermenéuticos de apropiación, a un trabajo inconsciente de transferencias desde lo ajeno a lo propio: "todas las palabras son en si y desde el principio, en cuanto a su significado, tropos» (Nietzsche, 2000, [III, 426], p. 92). Este mecanismo trópico permite ampliar los sistemas léxicos, creando acepciones nuevas gracias a la movilidad semántica de los términos que eran manejados en su uso cotidiano para otros cometidos. Ortega defenderá el interés lingüístico, hermenéutico y cognitivo de la metáfora, cuyo hábitat natural es la mente. Este dato pone de manifiesto que las metáforas participan del mismo impulso y sustancia que el verbum interius, de donde dimanan. Para el autor español no existen significados fijos y definitivos para cada una de las palabras, sino que aquéllos afloran en función del uso de éstas, por lo que define la metáfora como la emergencia de la duplicidad del significado de un término, es decir, lo esencial es que conserve el significado antiguo junto al nuevo. La metáfora desencadena una especie de condensación entre ideas emparentadas, y en virtud de tal fusión sobreviene el cambio de significado: «es esencial a la metáfora la pervivencia de la significación primitiva en el seno de la nueva y metafórica» (Marías, 1973, p. 51). Lo más notable de esta teoría es que la metáfora aparece como un evento de gran poder hermenéutico, ya que permite entender una cosa en términos de otra, volviendo así familiar lo extraño y facilitando la comprensión del mundo utilizando diferentes ángulos de aproximación: «la metáfora es, pues, una interpretación de la realidad; y vivimos en un mundo constituido principalmente por ellas; más aún, esas metáforas son fundamento de la realidad cotidiana» (Marías, 1973, p. 46).

¿Qué es lo que nos sucede cuando comprendemos una metáfora? ¿Qué experiencia ganamos? ¿Se trata de una sorpresa en donde salta la chispa entre lo que entendemos en primera instancia («constantes brillos de un imán») y lo entendido posteriormente («unos ojos»)? La experiencia de la metáfora, en tanto que fenómeno hermenéutico, pone de relieve el carácter lingüístico de cualquier acontecimiento apropiador: «toda interpretación implica una experiencia del mundo y ésta siempre es lingüistica» (López, 2000, p. 231). Pero partamos de la noción 
genérica de experiencia que propone y maneja Gadamer, para aplicarla al caso específico de la metáfora-interpretación: toda experiencia está sometida a la divergencia entre las expectativas y lo que sucede en realidad. Cualquier acontecimiento apropiador, en tanto que experiencia del mundo, y por ello experiencia lingüística, sólo tiene el valor de vivencia si existe una discordancia tensiva entre lo que preveíamos que iba a ocurrir y lo que finalmente ocurrió, es decir, «la experiencia es en primer lugar siempre experiencia de algo que (...) no es como habiamos supuesto» (Gadamer, 1995, p. 430). La experiencia suscitada por la metáfora nos demuestra que hay muchas maneras de decir las cosas, que no existe una sola forma completa, definitiva y perfecta de decirlas. En efecto, la gran lección que nos aporta toda experiencia que sea digna de tal nombre consiste, a fin de cuentas, en poner en evidencia nuestros límites, pues «la verdadera experiencia es aquella en la que el hombre se hace consciente de su finitud» (Gadamer, 1995, p. 433). Por eso, cada experiencia singular de la metáfora nos muestra que no se puede decir todo, que el verbum interius está expuesto al principio de inexpresabilidad, que ese todo es demasiado para nuestra capacidad lingüística. La experiencia de la metáfora se construye desde ese intento frustrado de plenitud expresiva que al final se ve recortado por las mismas palabras que pretendían transportarla.

\section{Rastreo histórico de la diferencia entre palabra interior y exterior}

Ya veremos en el siguiente punto que sobre esta frustración descansa el aspecto universal de la hermenéutica como verbum interius. Pero antes en éste vamos a perfilar históricamente la distinción entre palabra interior y exterior, porque sólo así estaremos en condiciones de mantener nuestro hilo argumental: las metáforas interpretan y manifiestan con su experiencia el aspecto universal de la hermenéutica que se halla en el verbum interius.

Quizá, la primera tematización de la doctrina que diferencia entre la palabra interior y la exterior, provenga de la oposición conceptual del estoicismo entre el lógos interno y el externo (lógos endiathetos y lógos prophorikos): «con esta distinción se pretendía destacar en origen el principio estoico del mundo que era el logos respecto a la exterioridad del puro hablar por imitación» (Gadamer, 1995, p. 503). O como afirma en otra parte el filósofo alemán refiriéndose a esta misma distinción: «ya en la Stoa se hablaba al respecto del "logos prophorikos" y "endiathetos", la asi llama- 
da "palabra interior", denominada en giro latino "verbum interius"” (Gadamer, 1998, p. 225). Y esto ya representa una diferencia fundamental entre los hombres y los animales, porque algunos de éstos pueden articular sonidos parecidos a los humanos, como loros y papagayos, por no hablar de otros más singulares como ladridos o graznidos, que parecen provenir de alguna desconocida intención expresiva. Decía Sexto Empírico que el hombre se distingue de las bestias no por el discurso proferido sino por el interior, ya que gracias a él puede hablar consigo mismo en silencio, cosa que todos podemos experimentar de manera constante (cfr. Long, 1987, p. 127). El estoicismo consideraba el "pensamiento articulado» como un proceso unitario y global que podía asumir dos aspectos diferenciados, como las dos caras de una misma moneda, que se concretaban en el acto de pensar y en el de hablar, lo cual significa que estas dos actividades son solidarias entre sí y no pueden ir cada una por su lado, sino que confluyen en una misma función conjunta que sólo puede disfrutar el ser humano. En efecto, el pensamiento ya es lenguaje, pues «todo pensar es un decirse» (Gadamer, 1995, p. 507). Desde la primera estoa, la proyección del "pensamiento articulado» sobre estas dos operaciones distintas aunque coincidentes, ya era considerada como un asunto de máxima importancia para su filosofía: "Crisipo parece haber establecido una distinción entre el pensamiento de uno y aquello que quiere decir, por una parte, y el aserto que un oyente puede atribuirle» (Long, 1987, p. 136).

La idea que asimila el pensamiento a una conversación sostenida desde la intimidad personal ya fue propuesta por Platón, así como la contraposición entre este discurso interior y el que se profiere en palabras sonoras, gráficas o gestuales, aunque el filósofo ateniense se refiere explícitamente al discurso vocalizado, como podemos ver en el diálogo que mantiene Teeteto con un Extranjero, donde éste le recuerda al otro: "el razonamiento y el discurso son, sin duda, la misma cosa, pero ¿no hemos puesto a uno de ellos, que consiste en un diálogo interior y silencioso del alma consigo misma, el nombre de razonamiento? (...) ¿Y no se ha denominado discurso al otro, que consiste en el flujo que surge de ella y sale por la boca, acompañado de sonido?» (Platón, 1992, Sofista 263e, p. 471). También en otro diálogo de la misma época podemos rastrear este pensamiento: dialogar uno consigo mismo es pensar, pero lo curioso del caso es que tal idea es expuesta en una conversación que entablan Teeteto y Sócrates como si pensaran juntos, en donde el primero le pregunta al segundo: "¿A qué llamas tú pensar?», a lo que Sócrates responde: «al discurso que el alma tiene consigo misma sobre las cosas que somete a consideración. (...) el alma, al pensar no hace otra cosa que dialogar y plantearse 
ella misma las preguntas y respuestas» (Platón, 1992, Teeteto 189e-190a, pp. $272-$ 273). Y continúa diciendo (190a): «al acto de opinar yo lo llamo hablar, y a la opinión un discurso que no se expresa (...) ante otro en voz alta, sino en silencio y para uno mismo». Podemos comprobar en estos diálogos la presencia de unos personajes que afirman que el alma dialoga consigo misma, igual que hizo Platón al escribirlos.

En San Agustín, la dualidad entre la palabra externa y la representada internamente se decide en el plano de la lengua, es decir, en el de un idioma en particular. Las lenguas naturales no manifiestan el verdadero ser de la palabra, ya que ésta se puede decir de muchas maneras; pero otra cosa es la palabra del verbum cordis, imagen refleja de la divina. Del mismo modo que antes de lanzar una piedra tenemos que haberlo decidido, es decir, las acciones voluntarias quedan señaladas con la vitola de la actividad interior, "pues nadie hace algo con su voluntad sin que lo haya dicho antes su corazón» (San Agustín, 2003, $\$ 41,[9,7, \$ 12]$ p. 160), también nuestras proferencias que salen de la boca y llegan a los oídos de los demás están contaminadas de esa misma actividad interior: "la palabra que suena fuera es signo de la palabra que brilla dentro» (San Agustín, 2003, \$ 49, [15, $11, \$ 20]$ p. 162). Expresiones como sensus interior, vis interior, intima scientia, homo interior, verbum interius, sentido íntimo, maestro interior, verbum cordis $\mathrm{u}$ ojo interior, revelan el hallazgo agustiniano de la interioridad humana: «en el centro está el hombre interior (...). El hombre es un ser con «intus», nueva dimensión de la realidad, modo inédito de ser que le permite obviar todo determinismo absoluto y todo "naturalismo» en general» (Uña, 1994, pp. 39-40). Nos gustaría mencionar, a tal respecto, la anécdota que refiere San Agustín en sus Confesiones cuando comprueba que, en contra de la costumbre de la época de leer en voz alta, el obispo de Milán, San Ambrosio (cfr. Lledó, 1994, p. 113, nota n. ${ }^{\circ}$ 5), leía para sí sin levantar la voz, escena que le produjo gran conmoción intelectual: «cuando él leía, recorrían las palabras los ojos y el corazón profundizaba el sentido, pero la voz y la lengua descansaban. Muchas veces, estando nosotros presentes (...) le vimos leer así en silencio» (San Agustín, 1991, VI, III, pp. 81-82). Considerando la diferencia entre la palabra interior y la exterior, es obvio que el mito cristiano del castigo divino de la confusión de lenguas en la Torre de Babel, expresa un fracaso comunicacional porque se quiebra la coincidencia comunitaria entre las diversas palabras externas, pero lo que no queda confundido es el verbum interius, garante básico del aspecto universal de la hermenéutica del que trataremos a continuación. 


\section{EI aspecto universal de la hermenéutica como verbum interius}

La reivindicación universalista de la hermenéutica ha generado algunos problemas, como el de creer que todo se puede reducir a lenguaje, y más a partir de la afirmación gadameriana que dice: «el ser que puede ser comprendido es lenguaje» (Gadamer, 1995, p. 567). Pero esta sentencia incluye un condicionamiento: el ser es lenguaje, sí, pero sólo el que puede comprenderse, cláusula que anula cualquier exigencia de panlingüisticismo. En efecto, ante la insinuación de Grondin, en un diálogo que mantuvo con su maestro, de que en Verdad y método se dejaba entrever que el ámbito del lenguaje no tiene límites, Gadamer le respondió: «iNo! ¡Yo no he pensado eso ni he dicho que todo sea lenguaje! El ser que puede entenderse, es lenguaje. En ello se encierra una limitación» (Gadamer, 2001, p. 371). Lo relevante ahí es la exclamación que advierte que él nunca ha pensado ni dicho que «todo es lenguaje», porque hay una limitación: «sólo el ser que puede ser comprendido». Así, Gadamer rechaza la acusación de panligüisticismo, y de paso cualquier intento de entender el aspecto universal de la hermenéutica en función de su conocida frase.

La pretensión de universalidad hermenéutica hay que situarla en otro lugar. Un día de otoño de 1988 en un restaurante de Heidelberg Grondin preguntó a Gadamer por el aspecto universal de la hermenéutica, "¿en dónde se halla éste?», a lo que contestó sin ambages: en el verbum interius. Cuando Grondin le pidió más explicaciones ante lo escueto de la respuesta, obtuvo otra: «la universalidad (...) se encuentra en el lenguaje interior, en el hecho de que no se puede decir todo. No se puede expresar todo lo que hay en el alma (...). Esta experiencia es universal" (Grondin, 1999, p. 15). No hay que entender la palabra interior como un trasunto inconsciente o una reserva semántica de carácter psicológico, como si las proferencias ya estuvieran fijadas antes de su emisión, más bien «se trata de aquello que aspira a exteriorizarse en el lenguaje expresado. (...) hay (...) sólo un mundo orientado hacia el lenguaje, que intenta dar palabra a lo que se quiere expresar sin conseguirlo del todo. Esta dimensión hermenéutica del lenguaje es la única que tiene carácter universal» (Grondin, 1999, p. 16). La pretensión universalista de la hermenéutica consiste, pues, en el deseo de decir aquello que existe como lenguaje interior. La aspiración, el deseo y la pretensión es lo universal en esa hermenéutica que intenta hacerse palabra externa en cada una de las lenguas de turno. Lo principal es el «querer decir», mientras que "lo dicho» es secundario. El estatuto del deseo con respecto al verbum interius queda así esclarecido, sobre 
todo si tenemos en cuenta el desfase que se decanta entre lo que se quería decir y lo dicho, insatisfacción que nos acompañará durante toda la vida para dar fe de nuestra constitutiva finitud humana: «la enunciación hablada siempre queda atrás con respecto del contenido de la enunciación, esto es, de la palabra interior, (...) sólo se puede comprender algo hablado si se reconstruye y verifica el hablar interior que está al acecho de lo dicho» (Grondin, 1999, p. 16). Y la metáfora, en tanto que dispositivo de interpretación de primer orden, también se verá afectada por el aspecto universal de la hermenéutica, marcado en origen por la palabra interior en su obstinada lucha por abrirse camino al exterior, aunque al aferrarse el ser humano al enunciado y a su aparente disponibilidad, esconda la lucha por el habla, deseo que constituye el verbum interius, es decir, la palabra hermenéutica (cfr. Grondin, 1999, p. 16).

La hermenéutica filosófica intentará comprender todo o parte de eso que no se puede decir, partiendo de lo que sí pudo decirse. Lo que consigue la diversidad de lenguas es mostrar el abismo, salvable en parte, entre el lógos interno y el externo: hay abismo porque lógos significa lenguaje y los referentes se pueden decir de muchas maneras, pero también ese abismo es salvable porque lógos además significa razón, y esto quiere decir que la formación de lenguas es activada desde la fuerza interna del lógos, desde ese deseo de decir y comprender que va construyendo la red conceptual compartida, desde la que los hablantes exteriorizan sus tramas semánticas y de sentido estableciendo, así, las conexiones entre cada palabra interior: "¿No es acaso el deseo el acto más elemental posible del lenguaje, en el sentido de que habita todo el esfuerzo de comunicación, a saber, que yo espero que mis palabras le harán comprender a usted lo que intento decirle?.) (Grondin, 2005, p. 84).

Podemos imaginar el verbum interius como una enredadera lingüística, y el lógos externo como una extensión de cada enredadera particular hacia una zona común en la que podemos engarzar los pensamientos expuestos. Este intento por exteriorizar la palabra interior hará que quede presa y disponible en la espesa urdimbre de la lengua compartida: «el mayor milagro del lenguaje no estriba en que la palabra se haga carne y aparezca en su ser externo, sino en el hecho de que lo que emerge y se manifiesta en su exteriorización es ya siempre palabra" (Gadamer, 1995 , p. 504). Cuando alguien pregunta a otro "¿qué quieres decir?», no pregunta por la estricta objetividad de lo dicho, por un mensaje codificado según unas reglas lingüísticas dadas sino por un deseo de sentido; pregunta por aque- 
llo que brotó desde su verbum interius, porque sabe que lo dicho se puede decir de muchas maneras, porque "todo» lo que se quiere decir no se puede decir, porque si se pudiera decir «todo» sólo habría un modo de hacerlo. La palabra interior no tiene gramática, aunque al exhibirse cristalice en una; carece de sintaxis, aunque para ver la luz se amolde a unas reglas, y tres cuartos de lo mismo sucede con la dimensión pragmática. Cuando decimos a alguien que tenemos que sacarle las palabras con sacacorchos, de poco nos sirve el código, ya que no es determinante en su valor de tabla de correspondencias como ocurre en los diccionarios; lo que hacemos, más bien, es activar en su verbum interius un camino para que ambos podamos transitarlo. La tensión dialéctica que se genera entre el lógos profóricos y el lógos endiácetos, sugiere que no puede existir un pensamiento separado del lenguaje, porque sólo «pensando encontramos las palabras oportunas; es más, los oyentes o los lectores sólo nos comprenden realmente cuando siguen el hilo de nuestro pensamiento en busca de palabras» (López, 2000, p. 238).

La palabra interior, esto es, el pensamiento que se tiene sobre algo, nunca puede abrirse paso más allá de los estrechos límites que el entendimiento discursivo impone. Éste no puede abarcar de un solo golpe todo lo que conoce, todas las relaciones que ha trabado y todo el contenido accesible a la memoria, por lo que no le queda más remedio que segregar secuencialmente aquello que es capaz de pensar, y disponerlo en la conciencia bajo la forma de una declaración interna no proferida. Y el tema sobre el que versan estas voces en off siempre es el mismo: hablan del ser humano que habita un mundo transido de murmullos, unos coloreados y otros transparentes. Si admitimos que el lenguaje permite tres mediaciones fundamentales, con uno mismo, con el otro y con el mundo, sería interesante preguntar por la prioridad de alguna de éstas; y la respuesta no sería otra que ese encuentro intervenido por el verbum interius, porque "decirse "el mundo" unicamente es posible si aquel que lo dice ha ido aprendiendo poco a poco, a "decirse a si mismo", a hablar consigo mismo" (Lledó, 2009, p. 158). De nada o de poco valen las sensaciones y las percepciones sordas, si no se integran en las redes lingüísticas que trenzaron las experiencias pretéritas. El verbum interius aparece, de esta manera, como el receptor más fino y avezado de la realidad. Gracias a su función mediadora, esta realidad nos alude, alcanza y requiere, pues «lo que dice la naturaleza es lo que nosotros vemos, lo que «nos decimos» desde ella. Ver el mundo es, por consiguiente, oír la voz con la que nosotros mismos constatamos su presencia. Entre el mundo del "noūs" y el de la "phýsis" no se interpone más que ese murmullo interior que se levanta en nosotros, cuando los sentidos fil- 
tran el aparecer ("phainoména") de la realidad. Pero es la consciencia la originadora de esa voz interion (Lledó, 1994, p. 70). Ni el lenguaje interior es algo aislado e independiente del mundo, ni éste es algo que pueda cobrar sentido sin aquél.

\section{El «carácter de acontecer» de la palabra}

Después de haber acreditado al principio de este trabajo el modo en que la metáfora demostraba sus poderes hermenéuticos, vimos también cómo el aspecto universal de la hermenéutica quedaba localizado en pleno verbum interius, ejerciendo desde ahí constantemente el deseo de hacer coincidir la palabra externa con la interna, un denodado esfuerzo siempre frustrado en parte, pero que ponía en evidencia la fuente originaria de nuestra discursividad, y también el modo en que la metáfora participaba de esa universalidad. Ahora, en el presente epígrafe, intentaremos mostrar que la relevancia hermenéutica de las palabras que somos capaces de producir, ya sea en clave metafórica o no, proviene no sólo del significado depositado en estas palabras que generamos (ergon), sino también del carácter fluyente y procesual que éstas presentan (enérgeia), pues el mero hecho de su propio acontecer las dota de un sentido que completa y refuerza su calidad hermenéutica.

¿Por qué el verbum interius es una palabra que no se emite en su totalidad? Si esta palabra ya estuviera dispuesta en el pensamiento y nos limitáramos a pronunciarla tal como nos aparece, sería imposible recorrer ese camino que el pensamiento va abriendo. Lo entendido no es una copia de lo armado mentalmente, sino la propia discursividad en tránsito haciéndose palabra. La metáfora del camino es fructífera porque alude a un desarrollo en donde se van devanando los contenidos; por eso, la palabra exterior es, en realidad, muchas palabras, porque el espíritu desconoce todo lo que el verbum interius sabe, es decir, «no sabe realmente lo que sabe», como le gusta decir a Gadamer, y por eso es preciso deshilar la madeja. Ocurre algo parecido en los exámenes (cfr. Gadamer, 1998, p. 227): el alumno no es consciente al instante de todo lo que sabe, pero las preguntas le irán indicando el camino que tiene que seguir para seleccionar las respuestas que habrá de entregar. Por esta razón, sugiere Gadamer que una buena forma de examinar sería mantener una conversación con el alumno, para que en ella se dibuje un flujo procesual que ponga de manifiesto el alcance de los conocimientos que aquél fue capaz de «encontrar», relacionar y mostrar. 
Gadamer percibe el carácter procesual de la palabra en esta secuencia activa in fieri, e ilustra el fenómeno con la interpretación de Tomás de Aquino sobre las diferencias entre el verbo divino y el humano: a) en el espíritu divino, a diferencia del humano, no hay disonancia entre lo que piensa y lo que dice; b) si la palabra humana se dispersa, disemina y fragmenta en multitud de referencias y relaciones, la divina es solamente una, y por eso la humana nunca dice todo lo que quisiera decir, teniendo que ser contrastada hermenéuticamente con lo que calló; y c) aunque la palabra humana señale la cosa nunca la abarcará por completo, tan sólo podrá aspirar a referirse a ella desglosándola en sucesivas acepciones y facetas. El desfase que aparece entre lo que queremos decir y lo que decimos, nunca podrá ser salvado en su totalidad, y nos obligará a mantener el deseo encendido y a postergar indefinidamente su satisfacción. Esta frustración, residuo de un proceso dialéctico imparable que se cuece en la conciencia, nos revela que el deseo patrocina las nuevas palabras externas al intentar, sin conseguirlo, hacerlas coincidir con las internas. Nunca llegará esa última palabra definitiva y justa, excepto la que nuestra constitutiva finitud pueda sellar como realmente última al acabar la existencia: «tenemos siempre la contradicción entre aquello que queremos decir y aquello que hemos dicho realmente, y hemos de dejar constantemente tras nosotros aquello que no es suficiente y lanzarnos a un nuevo intento de decin» (Gadamer, 1994, p. 88).

De todo esto podemos extraer una lección: «El carácter de acontecer forma parte del sentido mismo» (Gadamer, 1995, p. 512); es decir: el sentido de las palabras no puede desgajarse del propio acontecer de las proferencias en las que aquéllas comparecen. Por ejemplo, en la experiencia de la metáfora, lo relevante no es sólo la referencia escueta y directa sino también el sentido, por usar la terminología de Frege. Comprender una metáfora no es sólo dar con la «cosa» concreta a la que alude ("el padre intelectual de Alejandro Magno»), sino además captar el sentido que conlleva («el discípulo de Platón que se rebeló contra la Idea»). Todos pensamos en Aristóteles, pero cada metáfora provoca una experiencia distinta gracias a su "carácter de acontecer», ya que añade una nota expresiva al desvelar unos ingredientes y encubrir otros. Quien intente hallar en la metáfora tan sólo nuevos elementos léxicos intercambiables por sinonimia, estará descontando del sentido ese carácter de suceso, de acontecer de una determinada manera y no de otra, después de "aquello» y antes de «esto», formando un contexto y difuminando o modificando otro, aireando unas hebras del verbum interius y oscureciendo otras, haciendo resonar unos contenidos en detrimento 
de otros. Lo que se desea conseguir con la metáfora es una aproximación, tanto hacia la cosa como hacia nuestro interlocutor, y todo por haber descubierto un nuevo atajo hacia nosotros mismos.

Si decimos, por ejemplo, que la tramoya del lenguaje es el verbum interius, lo estaremos oponiendo al escenario, esto es, al lenguaje exterior. Si tomamos el lenguaje interior por la tramoya de un teatro, la experiencia de esta metáfora, de esta interpretación bajo esta perspectiva promovida por el deseo en su lucha por exteriorizar la palabra interior, despertará la unidad del concepto que suscita la oposición entre el escenario y la tramoya. Si decimos que el verbum interius es la tramoya del lenguaje, afirmamos con ello que la esencia de aquél consiste en no presentarse en escena, aunque sea condición necesaria de la función (del lenguaje). La experiencia de la metáfora implica un comprender, y por esto constituye un acontecimiento hermenéutico de apropiación: toda captación de una metáfora supone el encuentro con un evento hermenéutico que forma parte de tal comprensión. Esto es: el mero aparecer de la metáfora, al margen de lo que indique y tematice en el ámbito del significado, es parte integrante de su sentido. Y esto es debido a que el fenómeno hermenéutico de la metáfora acontece según el régimen fenomenológico de la experiencia, lo que quiere decir que no sólo es relevante la obtención de un producto semántico final que pueda o no con el tiempo lexicalizarse, sino que también es crucial el encuentro con esa novedad alternativa que viene articulada de acuerdo con la historicidad interna de la propia experiencia que ha logrado generar: «cuando se considera la experiencia sólo por referencia a su resultado se pasa por encima del verdadero proceso de la experiencia» (Gadamer, 1995, p. 428).

El deseo no está en lo dicho (eso sería la demanda), sino en lo que queda en la trastienda de las palabras. Las metáforas permiten ver al trasluz el deseo como una marca de agua, porque dejan percibir de algún modo el tipo de vínculo que el hablante imaginó entre un sin fin de ellos, declarando así sus carencias, sus objetos más queridos, su temporalidad, su satisfacción y su situación perceptiva; pero esto sólo ocurre cuando el deseo es proyectado al encuentro de conexiones creativas (lenguaje tensivo), y no sobre asociaciones manidas (estenolenguaje). Nos referimos a la distinción "entre el lenguaje estererotipado (lenguaje bloqueado, estenolenguaje), y el lenguaje vivo, fluido y (...) metafórico» (Wheelwright, 1979, p. 19), o lenguaje tensivo. Cuando usamos los clichés del lenguaje estereotipado por contraposición al tensivo, o la rigidez del espíritu literal que pretende preci- 
sión aséptica, ¿no estamos, acaso, guardando las distancias? ¿Y cómo comprender a alguien, a algo o a uno mismo, guardando las distancias?: «el diálogo interior es esa instancia que nos hace sentir un saludable sentimiento de extrañeza frente a las facilidades del lenguaje "exterior», ese mismo que lo banaliza y oscurece todo" (Grondin, 2005, p. 61).

\section{La dialéctica del diálogo interior: voces y demonios}

La constitución de la conciencia, su forma, función y estructura, implica una constante movilidad interna que la obliga a confrontarse consigo misma, produciendo en tal encuentro un curso de cambios donde se mantiene despierta y activa. Una conciencia estática, sin autodinamismo, dejaría de ser conciencia, pues «el curso de la conciencia, que ella elabora en sí misma, es un "movimiento dialéctico" ", tal y como dice Heidegger (2005, p. 191) interpretando al Hegel de la Fenomenología del Espiritu. Este movimiento es el mismo que resuena en Platón cuando dice que pensar es el propio diálogo del alma. La conciencia, haciendo gala de su específico modo de ser, nunca permanece idéntica a sí misma, pues eliminaría el «diá-» (a través de, entre) del diálogo que segrega desde su intimidad, «entre» su intimidad, «a través» de ella. Por eso, la palabra interior es ambivalente, dual, dialógica, y al pertenecer a la conciencia aprovecha su movimiento dialéctico que la constituye y perpetúa: «en la medida en que la formación de la conciencia ocurre "al mismo tiempo" en tanto que diálogo que se recoge y en tanto que recogimiento que se expresa, el movimiento de la conciencia es dialéctico» (Heidegger, 1996, [169], pp. 168-169, nuevamente interpretando a Hegel).

Si la palabra interior no pudiera contraponerse a nada, ni discrepar de nada, ni dialogar con nada, dejaría de ser palabra naciente y se convertiría en un automatismo que, como tal, sería dogmático al estar construido en base a un programa incapaz de trascenderse por definición. La palabra interior ocupa distintas posiciones, por lo que disfruta de varias perspectivas que suele contrastar: desde una situación dada (tesis) pasa a otra al cuestionar la anterior (antítesis), y así genera una nueva (síntesis) que dará lugar a otros movimientos, que no son más que el reflejo de su propio dinamismo. Esta suerte tética hace que la palabra interior, al dialogar consigo misma, cruce sus preguntas y respuestas con algo otro que ya la habitaba, producto de una división virtual pero necesaria de la que no siempre somos conscientes. La dualidad exigida para el diálogo queda reco- 
gida en tal escisión; sólo así se promueve una conversación a dos bandas dentro de sí, en donde cada parte se enajena de la otra para impulsar el deseo de hablarse mutuamente. Pero la vocación del verbum interius es estar dirigido «a otro», aunque éste sea también yo mismo: esta es «la verdad ontológica del lenguaje, a saber, que su estructura es siempre la de ser-para-el-otro. No existe lenguaje privado, interior, que no tenga esta estructura. Las afirmaciones inaudibles de mi hablar conmigo mismo reflejan el hecho de que soy un casi-otro para mi» (Laing y Cooper, 1973, p. 20).

El lenguaje presenta una impronta de carácter binario que lo determina. El diálogo no es una secuela más del lenguaje o una modalidad especial de éste marcada por el uso interpersonal, sino que es su origen y fundamento, porque sólo en la conversación encuentra su legítima esencia. De hecho, el lenguaje no se autentifica en su función nominativa, ni en sus posibilidades apofánticas, ni en el enunciado, sino que se cumple en el diálogo: «el lenguaje no pertenece a la esfera del yo, sino a la del nosotros y por eso su verdadero ser es el diálogo» (López, 2000, p. 234). Esto quiere decir que si no hallamos en nosotros una alteridad con la que conversar, un diferencial dialógico de preguntas y respuestas, estaríamos pervirtiendo la naturalidad del lenguaje, justamente por conformarnos con un estenolenguaje robotizado más propio de los metalenguajes encriptados en códigos. El lenguaje auténtico y natural es sólo aquél que hierve entre la polaridad vital de dos o más existencias únicas, irrepetibles e irreemplazables que entran en relación (plano dialéctico) porque cada una quiere algo de la otra (plano retórico), aunque sólo sea ser reconocida, manifestarse o llegar a algún acuerdo, y empleando, además, una forma lingüística y no otra (plano poético) debido al «carácter de acontecer» de la palabra. Ni que decir tiene que estos tres planos, aunque se desarrollan en el foro externo del lenguaje, hunden sus raíces en el ámbito interno de la conciencia. El verbum interius no es una palabra inerte, exenta de vaivenes y contradicciones, porque es producida en el toma y daca del alma consigo misma, que se pregunta y responde, tanto en el registro dialéctico como en el poético, pero que también alberga sus intenciones y querencias, como lo demuestra su marchamo retórico, expresión preferente de un deseo genético, de una vocación seductora que va en busca de un estado de cosas que no percibe en la realidad: «el diálogo del alma consigo misma puede tener un sentido dialéctico y retórico. El alma puede dialogar consigo misma sin aspirar a ningún género de convencimiento. $O$ sí. La reflexión interior es dialéctica pero también retórica. E incluso el primer terreno de la retórica es la propia conciencia. Porque principalmente debemos 
argumentar con vistas al convencimiento de nosotros mismos, y sólo secundariamente de los demás» (Garay, 2005, p. 342).

Pero, ¿cómo se presenta en el fuero interno ese segundo actor que hace que la representación no sea un monólogo? ¿De qué recursos se vale ese tramoyista que posibilita el diálogo en una escena en la que es imposible hacer mutis porque ya se desarrolla entre bastidores? El yo subjetivo o identificativo ha sido concebido filosóficamente al margen del yo autorreflexivo e introspectivo, y por eso se han postulado núcleos egoicos internos que conviven en los dominios de la conciencia o, a veces, más allá de sus borrosas fronteras, causando un rumor de pareceres y opiniones: «el pensamiento se escucha. Musa, genio, demonio de Sócrates, Mefistófeles de Fausto, hablan en el fondo del yo y lo guian (...); lo universal de Hegel, lo social de Durkheim, (...) el inconsciente de Freud, lo existenciario que sostiene lo existencial en Heidegger. Todas estas nociones no representan una oposición entre diversas facultades del yo, sino la presencia, detrás del yo, de un principio extraño que no se opone necesariamente al yo». (Levinas, 1995, p. 281). También se ha hablado de la voz de la conciencia enfatizando su vis ética. La concepción moral de la conciencia, de sus voces y demonios resulta, sin duda, muy interesante, pero nos preocupan más esas voces en tanto que voces dialógicas o de contraposto, lo que nos dicen y cómo lo hacen. Kant, por ejemplo, concibió la conciencia en tono moral, y afirmó que persigue al hombre como si fuera su sombra, porque no puede dejar de oír su voz (cfr. Conill, 2009, p. 118). Las críticas a la conciencia moral proceden principalmente de los llamados filósofos de la sospecha: Nietzsche mostró que detrás de la conciencia existe un fondo activo, histórico y cultural, pero también de instintos ciegos e imparables que hacen y deshacen a su antojo pasando por encima del venerado consciente volitivo; Freud hizo hincapié en esas instancias insonoras (inconsciente, ello, super-yo) que son más originarias y poderosas que ese yo derivado que el hábito burgués cree accesible a la introspección (por ello, precisamente, la tarea del psicoanálisis es hacer familiar lo extraño, convertir el ello en yo); y Marx descubrió la fuerza de los procesos sociales como un factor determinante de la supuesta moralidad de la conciencia (cfr. Conill, 2009, p. 119).

San Pablo recurrió al estoicismo para recuperar la idea de «palabra interior», con la intención de asociarla al poder natural que tiene el hombre para discernir el bien del mal, con lo que aparece el problema ético de la conciencia: ya se trate de una señal, un susurro, una corazonada o una luz interior, lo cierto es que 
la voz divina se hace eco en la conciencia. Pero anteriormente, siguiendo la doctrina estoica del pneuma, Cicerón y Séneca consideraron la voz de la conciencia como un espíritu que habita en nosotros, como "una fuerza, un poder, una rectitud, una "scintilla", la expresión de la "nata lex" (Conill, 2009, p. 117). Tradicionalmente se han empleado varios términos para aludir al conocimiento innato en el hombre de la ley moral, como acies cordis, mens, animi acies, aunque fueron las expresiones scintilla conscientiae y sindéresis las que hicieron mayor fortuna (cfr. Conill, 2009, p. 118). Recordemos, además, la importancia para Marco Aurelio del concepto "guía interior» o "principio rector» (hêgemonikón). La relevancia ética de la palabra interior es incuestionable, como ahora comprobamos y después veremos con el demonio de Sócrates, pero nosotros preferimos enfatizar el hecho lingüístico que supone que la misma conciencia se desdoble y opere dialécticamente para sostener un diálogo consigo misma, sin impedir el diálogo interpersonal, lo cual permite que ambos diálogos se retroalimenten.

La expresión «voz de la conciencia» quizá provenga de Heidegger, quien en su análisis ontológico afirma que es previa a cualquier descripción de carácter biológico, psicológico o teológico (cfr. Heidegger, 1993, \$54, p. 293). La voz de la conciencia es un fenómeno originario del Dasein pero, además, la autointerpretación cotidiana de éste (cfr. Heidegger, 1993, $\$ 54$, p. 292). Se revela como una llamada, como una apelación o, si se quiere, como una reclamación. En realidad, esta voz no dice nada en concreto, sólo es una llamada del propio interpelado hacia sí mismo: "la vocación viene "de" mí y sin embargo "sobre" mì (Heidegger, 1993, \$57, p. 299). Quien convoca es el Dasein en su desazón, exilio y angustia por encontrarse arrojado a un mundo lleno de posibilidades de las que es necesario pero difícil «cuidarse» y escoger alguna, aunque la voz de la conciencia ayude a ello. A esta llamada se la puede considerar un modo de habla, aunque no precise de la fonación de la voz, pero quiere ser escuchada y respondida y, por supuesto, comprendida: «a la vocación de la conciencia le responde un posible oin (Heidegger, 1993, $\$ 54$, p. 294) que descubre la notificación inquisidora sobre un acto o una omisión cometidos con respecto al abanico abierto de posibilidades. El aviso de esta voz es como un servomecanismo que de tanto monitorizar las constantes de la cura (Sorge), se siente inmerso en su más grave posibilidad, la de existir; por ello, la voz de la conciencia es la de su propia existencia, la de su propio deseo de existencia: “comprender la invocación” quiere decir: "querer tener conciencia”" (Heidegger, 1993, $\$ 58$, p. 313), desear estar sumido en aquello que la conciencia y su voz advierten. 
Zubiri aprovechó el análisis heideggeriano de la voz de la conciencia, pero se distanció del filósofo alemán para apoyar una interpretación que situaba esta voz en el clamor de una realidad que otorga al hombre la posibilidad de ser su portavoz. La voz de la conciencia es un fenómeno real, innegable e inapelable. La realidad ejerce un poder total sobre el hombre, y este mismo poder permite que el hombre sea también real: "la realidad se me hace presente como noticia en la voz de la conciencia» (Zubiri, 1994, p. 137). Pero, ¿en qué consiste esta voz? ¿De dónde procede y qué quiere? Esta voz surge desde el fondo de mi propio ser, desde un nivel más radical y primero que el tratado por la psicología. Esta voz siempre me apunta cosas, me prescribe algo. Puede ser nítida, confusa o titubeante, pero como es una voz que me habla desde lo más profundo de mi realidad, emerge con ella un mensaje sobre la postura que he de adoptar: «en cada instante de su vida el hombre posee (...) eso que se llama "voz de la conciencia". Es la voz que en una o en otra forma dicta al hombre lo que ha de hacer o no hacen" (Zubiri, 1994, p. 101). Pero no se trata de una voz que resuelve todos los problemas, y no siempre nos habla de deberes u ob-ligaciones, y menos aún hay que entenderla como si fuera una especie de imperativo categórico kantiano; se trata de «una voz en cuanto voz» (Zubiri, 1994, p. 103). La vista, por ejemplo, me hace presente la cosa en su eidos al hallarse bajo la tiranía de la imagen, pero la voz irrumpe según la forma de representación sonora de palabras que informan sobre la realidad. Si para Heidegger estamos arrojados a un mundo de posibilidades que hay que enfrentar queramos o no, para Zubiri nos hallamos sumidos en el enigma de lo real; si para Heidegger la voz de la conciencia es la voz de la existencia, para Zubiri es la voz de la problemática a la que me destinan mis propias acciones por las que me voy haciendo persona (cfr. Zubiri, 1994, p. 109).

Esta voz de la conciencia o verbum interius, antes de San Agustín, fue llamada por los griegos daimon. El daimon del hombre es su genio personal, su carácter (como diría Heráclito, fr. 119), su modo de ser más genuino y profundo, porque alude a la soberanía que dirige el ánimo pero sin restarle un ápice de libertad, ya que está unido a él por un vínculo de simpatía. El daímon proporciona inspiración e intuición, y llena el espíritu con las posibilidades de un mundo imaginado que quiere abrirse paso a la realidad. El término daimon podría significar en griego «el distribuidor», «el que reparte», «el que otorga bienes y favores» (cfr. Tovar, 1992, pp. 245 y 247). Estar poseído por el buen daimon (eu-daimon) de la buena suerte o del buen presagio, engendra el bien-estar, el bien-hacer y el bien-vivir en el mundo. Este demonio puede ser escuchado como una voz que 
procede de las entrañas, aunque «tener un buen demonio, buena fortuna, buena suerte, es algo que parece venir de unos poderes que escapan de nuestra voluntad y de nuestros deseos" (Lledó, 1998b, p. 97). Hay que hacer caso a lo que dicen esas voces que inventamos en las relaciones personales, en los textos, en las imágenes, en los sonidos, en cualquier situación. Hay que escuchar a los demonios que llevamos dentro, las palabras que nos habitan, pues nos hablan de la unidad última de nuestros fines que se concretan en la felicidad (prosperidad, posesión de bienes, estado de paz, de serenidad interior), pues esto es lo significa el término griego, eudaimonía: «lo primero que el término sugiere (...) es una cierta resonancia mítico-religiosa: formado por dos elementos, "eu" y "daimonía", de los que el segundo — derivado de "daimon": genio o divinidad de rango medio- apela a una situación algo más que humana y a la que el primero califica como "Bueno", "eudaimonia" significaría algo asi como "el hecho de estar bajo la protección de un genio propicio"». (Samaranch, 1991, p. 226).

El daimon es tanto la divinidad como el designio. Usado en singular era una especie de semidiós que intervenía en el destino de los hombres, y en plural, la cohorte de dioses menores, de seres sobrehumanos o las almas de los difuntos. A veces se traduce como duende, dios, demonio o la voz interior que aflora en los sueños (cfr. Tovar, 1992, p. 247) y en la vigilia, aunque fue Sócrates quien perfiló su naturaleza y actividad, como así nos cuenta Tovar en este surtido de referencias a los diálogos platónicos: "la naturaleza del "daimon" fue entendida por Sócrates como esencialmente negativa. (...) El demonio siempre le disuade, nunca le da órdenes. Le impide ora que se vaya [Fedro $242 \mathrm{~b}-\mathrm{c}$ ] hasta que repare una falta. Ora que trate a ciertas personas [Teeteto $151 \mathrm{~b}$ ], bien que se levante para irse antes de tener un encuentro de cierto interés intelectual [Eutidemo 272 e], bien que le exprese a Alcibiades su afición [Alcibiades I 103 a, 105 d, 124 c], bien que se meta en política» (Tovar, 1992, p. 252). A veces emerge en Sócrates algo divino y demoníaco, y desde su infancia una voz se hacía oír en su interior para impedirle llevar a cabo lo que había estado a punto de hacer. Esta voz interior nunca le había empujado a la acción. Se trata de una señal: «hay junto a mi algo divino y demónico. Está conmigo desde niño, toma la forma de vozy, cuando se manifiesta, siempre me disuade de lo que voy a hacer, jamás me incita» (Platón, 1997a, Apología 31 c-d, p. 170). Como podemos comprobar, a Sócrates le es suficiente con las advertencias negativas de su daimon que le dictan lo que debe evitar, mientras que en los demás casos se deja guiar por su propio criterio, porque interpreta el silencio de su demonio como una tácita aprobación (cfr. Tovar, 1992, p. 257). 
Pero Sócrates también concedía al daímon ciertos poderes hermenéuticos, unas cualidades propias de un traductor experto en mediar entre los hombres y los dioses, en hacer comprender a unos y a otros los mensajes que se intercambiaban. En efecto, en el Banquete se presenta a Eros, al Amor, como un gran demonio, como una entidad metafísica cósmica que se dedicaba a ejercer de médium entre lo divino y lo humano: «—iQué puede ser, entonces, Eros? (...). -(...) algo intermedio entre lo mortal y lo inmortal. (...) - Un gran demon, Sócrates. Pues también todo lo demónico está entre la divinidad y lo mortal. —iY qué poder tiene? (...). - Interpreta y comunica a los dioses las cosas de los hombres y a los hombres las de los dioses. (...) Al estar en medio de unos y otros llena el espacio entre ambos, de suerte que el todo queda unido consigo mismo como un continuo" (Platón, 1997b, Banquete 202 d-e, pp. 246-247). Al actuar Eros como un poderoso vínculo (sýndesmos) que mantiene todo unido, podríamos ver en este peculiar demonio la racionalización de la energía del deseo que, procurando atracciones y querencias, asegura la cohesión entre los seres humanos, porque sólo es necesario construir un puente cuando hay que vadear un río, un abismo, una separación. El ser humano, por tanto, es un ser a medio camino entre el cielo y la tierra, porque no es ni divino ni animal, tan sólo un habitante del límite que a veces sale al encuentro de la otra parte a la que asiste para provocar la chispa que ilumina, al menos durante un instante, su actividad deseante, hermenéutica y ética, y que puede desembocar en una conjunción feliz de diversos niveles de comprensión, una reunión simbólica de las insólitas fuerzas que le configuran: «el encuentro del sujeto con su "daimon" debe determinarse como "acontecimiento simbólico", un encaje entre esas dos partes del sujeto (él mismo y su "daímon"). (...) el "daimon" se presenta ante el sujeto como la brújula misma de su deseo y pasión (de su erótica, de su capacidad de desear y querer)» (Trías, 2001, p. 233).

\section{Conclusiones: el verbum interius como metáfora de la (auto) comprensión}

Una de nuestras primeras conclusiones podría ser formulada en los siguientes términos: cualquier interpretación que venga de la mano de una metáfora, provocará una experiencia lingüística del mundo. Y para obtener todo el rendimiento posible a esta conclusión, vamos a proponer como metáfora conductora y fractal el propio verbum interius. En efecto, la expresión compuesta «verbum interius» ya es una metáfora, aunque la traduzcamos quizá correctamente por 
«palabra interior». Pero, ¿«interior» a qué? ¿Es conmensurable el espacio lleno de aire que vibra y transmite las ondas sonoras de la palabra proferida, con ese otro sin posición física pero que ubicamos en la mente? Creemos que no; pero es curioso el modo en que solemos asimilar las palabras de escaparate que nos suministra el otro, y que alojamos en el mismo lugar habilitado por nuestras palabras interiores, esas que tal vez no digamos nunca. Es más, esta palabra que llega del exterior y nos toca, es capaz de despertar otras que latían en la tramoya confortable del lenguaje. Este fenómeno nos recuerda la experiencia que hemos vivido al pretender explicar el significado del verbum interius, con la intención de practicar una especie de trabajo de campo para comprobar de modo recursivo, si ese verbum interius, responsable máximo de la universalidad de la hermenéutica, podía ser percibido y localizado por nuestro interlocutor al ser activado desde el lógos externo. ¿Qué otras nuevas metáforas puede arrancar la autocomprensión del verbum interius?

Un profesor de física nos sugirió la idea de que el verbum interius podía ser entendido en términos del efecto fotoeléctrico, fruto de las investigaciones de Einstein en 1905. ¿En qué consiste tal efecto?: "Una placa de metal expuesta a la luz ultravioleta adquiere carga eléctrica. (...) la luz posee la propiedad de extraer las particulas de carga negativa de la superficie de metales expuestos. Estas particulas cargadas son (...) electrones. Así, pues, la luz, que es una onda electromagnética, puede transmitir energía a los constituyentes de un metal, aumentar su agitación y permitirles escapar del mismo cuando dicha agitación es suficientemente intensa» (Deligeorges, 1990, p. 29). Esta metáfora planteaba un contexto muy distinto al de los estoicos, al de San Agustín, al de la escolástica y al de la hermenéutica filosófica, pero era perfecta: la placa de metal era el verbum interius expuesto a la luz ultravioleta, es decir, a la palabra exterior del otro, que es capaz de activar (carga eléctrica) contenidos latentes (lo no dicho) que podrían ser manifestados (lo dicho) en proferencias nunca utilizadas. Posteriormente hallamos una cita de Ortega que reflejaba la experiencia del despertar del verbum interius, otra modalidad metafórica de la activación de la palabra interior, esta vez sin ningún efecto fotoeléctrico por medio, pero que en cierto modo lo conmemoraba: «Nunca he podido leer las páginas de un libro sin que por deliciosa repercusión se levantasen dentro de mi bandadas de pensamientos» (Ortega, 1998, p. 51). La lectura vendría a ser la exposición a la palabra exterior del otro, a la luz ultravioleta, que tiene el poder de «extraer partículas», de «levantar bandadas de pensamientos» de nuestro verbum interius. 
¡Qué diferencia tan abismal entre la metáfora del efecto fotoeléctrico y la de Ortega! ¡Qué mundos tan desiguales! ¡Qué ontologías regionales tan extrañas entre sí:: la del contexto físico (carga eléctrica, luz ultravioleta, ondas, electrones, superficies de metal, fotones), y la que está a la escucha hermenéutica (verbum interius, lógos externo, «lo no dicho» en «lo dicho», sentido, comprender, buscar la palabra interior del otro). Ambas se refieren a fenómenos bien dispares, pero si se buscan las metáforas adecuadas pueden ser nivelados. Sólo si tenemos presente la existencia de ese lenguaje dialógico y mudo de cada uno, podremos aspirar a comprender lo que se intenta decir; sólo si prestamos oído al verbum interius abriremos una brecha en la fachada del discurso encorsetado de las reglas de la gramática y la semántica normalizada de glosario y dicción. La experiencia de la metáfora tendrá que ser abordada también desde el lenguaje interior, que es el que nos acopla en resonancia con ella, porque lo que queremos es entender y ser entendidos: «ese lenguaje interior es el que lleva en su seno el lenguaje efectivo, en el sentido preciso de que es éste, precisamente, el que buscamos entender cuando nos encontramos al acecho del sentido de las palabras. (...) este lenguaje no se podría codificar o encajonar en estructuras) (Grondin, 2005, p. 62). En efecto, la relación existente entre la metáfora, la hermenéutica y el aspecto universal de ésta, vendrá constituida en base al verbum interius, con lo que podemos obtener una segunda conclusión: en la medida en que la metáfora exhibe su poder hermenéutico, queda marcada por la impronta del verbum interius, en tanto que éste es el responsable del aspecto universal de la hermenéutica.

Podríamos creer que un pretendido entendimiento podría venir de la coincidencia calcada entre las proferencias manifestadas. Por ejemplo, si una persona dice: «no me puedo quejar», y otra afirma lo mismo, ambos estarían de acuerdo. La identidad entre ambas proferencias es total, pero ¿quieren decir lo mismo las dos personas? El problema de reducir el lenguaje exclusivamente al lenguaje exterior nos puede hacer olvidar que el sentido, tal vez, pudiera no ser el mismo (más allá de la variedad de contextos). Esta cuestión resulta relevante en la medi$\mathrm{da}$ en que muestra que no todos abrigamos las mismas intenciones ni las mismas expectativas, que lo que callamos («lo no dicho» en "lo dicho») no es idéntico, aunque lo declarado sea una copia exacta de las palabras del otro, porque la palabra «no tiene su «esencia» en su completa enunciación, sino en lo que deja sin decin» (Gadamer, 2002, p. 78). De ese efecto hermenéutico se percató Ortega, quien recomendaba una receta filológica antigua que debería acceder al rango de principio hermenéutico: "Duo si idem dicunt no est idem", "Si dos dicen lo mismo, ya no es lo mismo"» (Ortega, 1983, p. 93). 
Si lo que pretende la hermenéutica en su proyección universalista es hacerse cargo de la palabra interior, el significado de una misma proferencia en boca de dos hablantes con respecto al verbum interius de cada uno, nunca será el mismo. Por eso dice Ortega que muchos hombres, aunque hayan dicho una frase con el mismo significado objetivo, es decir, con las mismas palabras, nunca tendrá para cada uno la misma función vital expresiva, ya que la condición de cada cual, su circunstancia, nunca será igual: «la frase que un hombre escribe o pronuncia tiene una significación que podemos llamar objetiva (...). Pero al haber entendido esta idea enunciada por la frase no hemos entendido aún ésta en su efectivo, concreto y real sentido. (...) Si al querer entender una idea prescindimos de la circunstancia que la provoca y del designio que la ha inspirado, tendremos de ella sólo un perfil vago y abstracto» (Ortega, 1983, pp. 92-93). Este pensamiento marca una diferencia crucial entre la semántica y el sentido, entre el significado material de las palabras y la interpretación viva que es preciso recoger. Esa misma frase que cien personas pronuncian o escriben no está arrancada del mismo fondo de experiencias solidificadas en el lenguaje, no encaja de igual manera sobre la trama lingüística que cada uno omite, no expresa la misma pretensión, aunque un examen «objetivo» certifique que está sostenida por los mismos códigos: «la hermenéutica aborda más bien la cuestión del sentido a partir del interior, del sentido que nos hace vivir, pero lo hace prestando oídos a lo que no está dicho, a lo que no llega a decirse, al lenguaje que se busca y que sería fatal reducir a meros códigos» (Grondin, 2005, p. 65). Y a partir de aquí podemos extraer nuestra tercera conclusión: si el aspecto universal de la hermenéutica se encuentra en el lenguaje interior, que consiste en la experiencia universal de querer y no poder decirlo todo, esta lucha por la palabra representará un deseo de decir que, aunque no se satisfaga por completo, quedará plasmado de alguna manera en cada metáfora que consiga ver la luz; o lo que es lo mismo: si el deseo asiste a cada desarrollo hermenéutico, la experiencia de la metáfora en su carácter de acontecer, llevará su sello.

El estructuralismo quizá acierte al proponer una teoría lingüística que toma como objeto de estudio las proposiciones que revelamos (como un juego de oposiciones e interdiferencias en distintos niveles), pero falla al no poder articular en estructuras, de la misma forma, ese otro lenguaje interior. Del mismo modo que es obvio que las "cosas" y los significados se pueden enunciar de muchas maneras, atendiendo cada cual a sus voces y demonios internos, también es evidente que al no disponer todos de las mismas vivencias y del mismo universo lingüístico, no podemos conceder el mismo sentido a la misma proferencia. Pero lo cier- 
to es que el lenguaje exterior permite vislumbrar, tal vez por un efecto de resonancia, parte de ese otro discurso insonorizado, ese que nunca podemos destilar del todo pero que vamos buscando cuando nuestro deseo pasa por comprender al otro y a nosotros mismos. Sólo podemos entender en la medida que hacemos sitio en nuestro verbum interius para que las palabras se acoplen en él; de esta forma nuestra voz interior llegará a ser realmente anfitriona de la alteridad lingüística, de la palabra que viene de afuera y se mezcla con la interna. La dualidad necesaria que estructura la conciencia para que sea posible el diálogo interior, pone al descubierto el deseo que subyace en cada uno de los dos polos virtuales y dialécticos, que es el mismo deseo que recogíamos a propósito del aspecto universal de la hermenéutica.

La misma metáfora no es la misma metáfora, si dos dicen lo mismo ya no es lo mismo, si dos dicen cosas distintas quizá su sentido sea idéntico, si logramos exponer parte de nuestra palabra interior tal vez sea posible llegar a un acuerdo: todas estas frases están extraídas del mismo talante hermenéutico. Si nos conformamos con la langue de bois que emplean los medios de comunicación, los discursos electorales (más partidistas que políticos), y el uso empobrecido cotidiano, estaremos contribuyendo a reducir al mínimo la posibilidad de enriquecer el lógos común, que debería estar abonado con la participación de cada verbum interius. No es que exista un lenguaje bueno, importante o verdadero, y otro malo, estéril o falso; tanto el lenguaje interior como el exterior (sobre todo si se aplica como lenguaje tensivo y no como estenolenguaje), son necesarios y deben complementarse para que la comprensión interhumana sea fluida y productiva. Lo que sucede es que si consideramos al lenguaje exterior como el único exponente del rendimiento lingüístico, estaremos dejando escapar la otra mitad, responsable del sentido que intentamos expresar y comprender: «el sentido del lenguaje no reside nunca en él mismo, o en las "estructuras" que hacen su sintaxis, sino en lo que él da que pensar, que compartir, que vivir, que esperar. Ese sentido es el diálogo interior, ese que nos agita y que sin cesar buscamos expresar cuando hablamos, sin que nunca podamos lograrlo totalmente (fracaso que confirma, no obstante, que ese lenguaje interior constituye la fibra más intima del lenguaje)" (Grondin, 2005, p. 60). Contando con el espíritu de esta última cita se impone una nueva conclusión: el hecho de experimentar la finitud humana en los procesos metafóricos-hermenéuticos, justamente por no poder decir todo lo que el verbum interius quisiera, consigue que quede en evidencia el deseo, un deseo insatisfecho y por eso vivo, pero que comparece junto con nuestra autocomprensión. 
Cuando decimos que el lenguaje visible y el oculto se complementan, no queremos provocar la imagen que producirían, por ejemplo, dos medias naranjas al totalizar una sola pieza. Más bien nos gustaría suscitar otro tipo de figuración un poco más sofisticado, y que vendría sugerido a través de esta nueva metáfora: imaginemos un caldero lleno de agua en la lumbre. El agua comenzará a hervir y a desprender vapor. El agua en estado líquido es el lenguaje interior, y el vapor es el exterior. Los líquidos no pueden ser respirados (el verbum interius no se puede oír), solamente los gases pueden ser respirados (las proferencias pueden ser captadas directamente), pero el vapor respirado termina por precipitarse como agua líquida. Quien no supiera que el vapor procede del agua en ebullición no se detendría a considerar su origen líquido, y creería que todo el agua (todo el lenguaje) no es más que vapor (lenguaje externo). Con algo de imaginación esta metáfora podría ser exprimida un poco más para obtener otro elemento significativo: sería posible tomar el fuego que hace hervir el agua por el deseo. Pero lo que queremos dejar claro es la heterogeneidad estructural que existe entre la palabra "líquida» del adentro y la "gaseosa» del afuera, aunque ambas no sean más que lenguaje (agua), dos palabras separadas y unidas por el deseo (fuego).

\section{Bibliografía}

ARistóteles (2002): Poética. (Tr.: S. Mas). Biblioteca Nueva. Madrid.

Bustos GuAdaÑo, E. (2000): La metáfora. Ensayos transdisciplinares. F.C.E. y U.N.E.D. Madrid.

Conill-SANCHO, J. (2009): “"La voz de la conciencia”. La conexión noológica de moralidad y religiosidad en Zubiri», Isegoría. Revista de Filosofía Moral y Política, n. ${ }^{\circ} 40$, enero-junio. Madrid.

Deligeorges, S. (1990): «La catástrofe ultravioleta», en Deligeorges, S. (Ed.), El mundo cuántico. (Tr.: M. ${ }^{a}$ C. Martín Sanz). Alianza Editorial. Madrid.

GadAmer, H.-G. (1994): «La idea de lógica en Hegel», en La dialéctica del Hegel. Cinco ensayos hermenéuticos. (Tr.: M. Garrido). Cátedra. Madrid.

- (1995): Verdad y método I. Fundamentos de una hermenéutica filosófica. (Tr.: A. Agud Aparicio y R. de Agapito). Sígueme. Salamanca.

- (1998): «Europa y la "oikoumene”», en El giro hermenéutico. (Tr.: A. Parada). Cátedra. Madrid. 
- (2000): «La diversidad de Europa. Herencia y futuro», en La herencia de Europa. Ensayos. (Tr.: P. Giralt Gorina). Península. Barcelona.

- (2001): «Diálogo donde se pasa revista a la obra de Gadamer y se da fe de su recepción histórica», en Antología. (Tr.: C. Ruiz-Garrido y M. Olasagasti). Sígueme. Salamanca.

- (2002): «El lenguaje de la metafísica», en Los caminos de Heidegger. (Tr.: A. Ackermann). Herder. Barcelona.

GARAY, J. DE (2005): «Hermenéutica y formas aristotélicas de racionalidad», en Oñate y Zubía, T.; García Santos, C. y Quintana Paz, M. Á., Hans-Georg Gadamer: Ontología estética y hermenéutica. Dykinson. Madrid.

GRONDIN, J. (1999): Introducción a la hermenéutica filosófica. (Tr.: A. Ackermann). Herder. Barcelona.

- (2005): Del sentido de la vida. Un ensayo filosófico. (Tr.: J. Dávila). Herder. Barcelona.

Hegel, G. W. F. (1983): Estética. 3: La forma del arte simbólico. (Tr.: A. Llanos). Siglo Veinte. Buenos Aires.

Heidegger, M. (1993): El ser y el tiempo. (Tr.: J. Gaos). Planeta-De Agostini. Madrid.

- (1996): «El concepto de experiencia en Hegel», en Caminos de bosque. (Tr.: H. Cortés y A. Leyte). Alianza Editorial. Madrid.

— (2005): «Dilucidación de la «Introducción» de la «Fenomenología del espíritu» de Hegel», en Hegel. (Tr.: Dina V. Picotti C.). Prometeo Libros. Buenos Aires.

LAING, R. D. y CoOper, D. G. (1973): Razón y violencia. Una década de pensamiento sartreano. (Tr.: M. Eguía). Paidós. Buenos Aires.

LEVINAS, E. (1995): Totalidad e infinito. Ensayo sobre la exterioridad. (Tr.: D. E. Guillot). Sígueme. Salamanca.

LlEDÓ, E. (1994): El surco del tiempo. Meditaciones sobre el mito platónico de la escritura y la memoria. Círculo de Lectores. Barcelona.

- (1998a): «Lenguaje y memoria», en Imágenes y palabras. Ensayo de humanidades. Santillana, Taurus. Madrid.

- (1998b): «Introducción a las Éticas», en Aristóteles, Ética nicomáquea. Ética Eudemia. Gredos. Madrid.

- (2009): «De Universidad y Educación», en Ser quien eres. Ensayos para una educación democrática. Prensas Universitarias de Zaragoza. 
LOCKE, J. (1994): Ensayo sobre el entendimiento humano. (Tr.: E. O'Gorman). F.C.E. Santafé de Bogotá, Colombia.

LONG, A. A. (1987): La filosofía helenistica. Estoicos, epicúreos, escépticos. (Tr.: P. Jordán de Urries). Alianza Editorial. Madrid.

LÓPEZ SÁENZ, M. ${ }^{\mathrm{A}}$ C. (2000): «La universalidad del lenguaje en la filosofía hermenéutica de H. G. Gadamer», en Racionero, Q. y Royo, S. (Eds.), Revista Éndoxa. La filosofía en el fin del siglo. Materiales para un análisis del pensamiento del siglo XX. (Series Filosóficas, n. ${ }^{\circ}$ 12, vol. I). U.N.E.D. Madrid.

Marías, J. (1973): Ortega. Circunstancia y vocación 2. Revista de Occidente. Madrid.

NiETzSCHE, F. (2000): «Descripción de la retórica antigua (1872)», en Escritos sobre retórica. (Tr.: L.E. de Santiago Guervós). Trotta. Madrid.

Ortega y Gasset, J. (1983): "Goethe», en Goethe-Dilthey. Revista de Occidente y Alianza Editorial. Madrid.

_- (1998): Espiritu de la letra. Cátedra. Madrid.

Platón (1992): Diálogos V (Parménides, Teeteto, Sofista, Político). (Tr.: M. ${ }^{a}$ I. Santa Cruz, Á. Vallejo y N.L. Cordero). Gredos. Madrid.

- (1997a): Diálogos I (Apología, Critón, Eutifrón, Ion, Lisis, Cármides, Hipias Menor, Hipias Mayor, Laques, Protágoras). (Tr.: J. Calonge, E. Lledó y C. García Gual). Gredos. Madrid.

- (1997b): Diálogos III (Fedón, Banquete, Fedro). (Tr.: C. García Gual, M. Martínez y E. Lledó). Gredos. Madrid.

Ricoeur, P. (1999): “¿Qué es un texto?», en Historia y narratividad. (Tr.: G. Aranzueque). Paidós. Barcelona.

San Agustín (1991): Confesiones. (Tr.: F. Montes de Oca). Porrúa. México.

SAN Agustín (2003): «De la trinidad», en El maestro o Sobre el lenguaje, y otros textos. (Tr.: A. Domínguez). Trotta. Madrid.

Tovar, A. (1992): Vida de Sócrates. Círculo de Lectores. Barcelona.

TRÍAS, E. (2001): Pensar la religión. Destino. Barcelona.

SEARle, J. R. (1999): "Metáfora», en Valdés Villanueva, L. M. (Comp.), La búsqueda del significado. Lecturas de filosofía del lenguaje. (Tr.: L. M. Valdés). Tecnos. Madrid.

Samaranch Kirner, F. DE P. (1991): Cuatro ensayos sobre Aristóteles. Politica y ética; metafisica. F.C.E. Madrid. 
Turbayne, C. M. (1974): El mito de la metáfora. (Tr.: C. Paschero). F.C.E. México.

Uña JuÁreZ, A. (1994): San Agustín (354-430). Ediciones del Orto. Madrid.

VICO, G. (1985): Principios de ciencia nueva (v. 1). (Tr.: J. M. Bermudo). Orbis. Barcelona.

Villar EzCurra, A. (1988): Pascal: ciencia y creencia. Cincel. Madrid.

WheElWright, P. (1979): Metáfora y realidad. (Tr.: C. A. Gómez). Espasa-Calpe. Madrid.

ZubIRI, X. (1994): El hombre y Dios. Alianza Editorial y Fundación Xavier Zubiri. Madrid.

Recibido: $15 / 08 / 2010$

Aceptado: 10/11/2010 